\title{
Morphological and physiological changes during maturation of okra seeds evaluated
}

\section{through image analysis}

\author{
Rayssa Fernanda dos Santos ${ }^{\circledR}$, Francisco Guilhien Gomes-Junior ${ }^{\circledR}$, Julio Marcos-Filho* (i)
}

Universidade de São Paulo/ESALQ - Depto. de Produção Vegetal, Av. Pádua Dias, 11 - 13418-900 - Piracicaba, SP - Brasil.

*Corresponding author <juliomarcos.1@usp.br>

Edited by: Lincoln Zotarelli

Received August 30, 2018

Accepted November 21, 2018
ABSTRACT: This study was performed to associate specific morphological parameters, defined by X-ray images, with seed performance of okra (Abelmoschus esculentus (L.) Moench) during maturation. Fruits of cultivar Santa Cruz 47 at different developmental stages were collected at five-day intervals (from 5 to 65 days after anthesis) and water content, dry matter, germination and vigor were determined in seeds extracted immediately after each harvest or after temporary storage for seven days. X-ray tests were also performed after each harvest and the images were analyzed by Image ${ }^{\circledR}$ software to produce data of aspect ratio (relation between major and minor axes of the ellipse surrounding the seed perimeter) and percentage of free space area in the inner seed cavity. Physiological maturity (maximum accumulation of dry matter) was reached at 30 days after anthesis (DAA), when seed water content was $56.6 \%$. Seed germination and vigor increased during maturation, achieving the maximum at 50 DAA. Seeds showed morphological changes during maturation, becoming more spherical (aspect ratio near 1.0); at the same time, the free space available in the inner cavity of the seed decreased. This parameter can be successfully used as a marker of physiological maturity when values equal or lower than $5 \%$ are reached.

Keywords: physiological potential RGB, aspect ratio, free space, seed maturity

\section{Introduction}

Okra is one of the main vegetable crops grown in tropical and subtropical regions of Africa, Asia, and Latin America. Brazil is among the five main producers worldwide. The species has an indeterminate growth habit, resulting in lack of uniformity of flowering and seed maturation, hindering the establishment of adequate time for harvest (Setubal and Nascimento, 2014).

Maturation is a process of seed metabolic and physiological changes that culminates with maximum accumulation of dry matter (Delouche, 1971; Chamma et al., 1990; TeKrony and Egli, 1997). Seeds produced in fleshy fruits are usually kept in high water content, protected by the fruit structure. In those species, the possibility of the seed maturation process to continue after the fruit harvest is an advantage because it allows early harvest, keeping fruits under temporary storage or a post-harvest rest period, sufficient for immature seeds to achieve a developmental degree similar to fruits harvested at physiological maturity. This allows the production of seed lots of high germination and vigor and avoids prolonged exposure of fruits to less favorable effects of biotic and abiotic factors in the field (Nascimento et al., 2000; Araujo et al., 2007; Vidigal et al., 2009, and Silva et al., 2015).

Evolution of seed maturation has been characterized by biochemical, molecular, physical, physiological and morphological parameters, including age and fruit color (Marcos-Filho, 1980; Gomes-Junior et al., 2017). The use of tools, such as the Munsell color chart (Kollmorgen Corporation, 1976) and the red, green, and blue (RGB) computer vision systems (Vidal et al., 2013) to identify the stage of fruit and seed maturation, may represent important actions to produce more precise color evaluations (Gomes-Junior et al., 2017).

Another resource is the computerized image analysis of seeds and seedlings for maturation studies. Research in this area includes more detailed observations, such as the attempt to establish relations between the ratio of the area occupied by the embryo or the available space in the inner cavity of the seed with germination and vigor, as highlighted by Dell'Aquilla (2009), Gagliardi and Marcos-Filho (2011), Silva et al. (2012).

Computer vision methods have also been useful to determine relations between physical parameters (size, shape, perimeter, area, and degree of roundness) and seed physiological potential. One of the parameters that can be used in studies on seed maturation is the aspect ratio (Wendt et al., 2014).

This study was performed to monitor the maturation process of okra seeds collected from fruits temporarily or not stored after harvest and evaluate the relationship of seed morphological parameters defined from $\mathrm{X}$-ray images (free space in the inner seed cavity and the degree of roundness) with seed physiological potential.

\section{Materials and Methods}

The study was conducted on okra seeds of cultivar 'Santa Cruz 47', one of the cultivars most recommended for growing in different regions of Brazil, for its high yield, adaptation to different climatic conditions, and production of high quality seeds. The cultivar meets the main market demands, such as long, cylindrical, smooth, and bright green color fruits. The field experiment was performed in Piracicaba, São Paulo State, Brazil (22 $43^{\prime} 30^{\prime \prime} \mathrm{S}, 47^{\circ} 38^{\prime} 51^{\prime \prime} \mathrm{W}$, and $524 \mathrm{~m}$ altitude). 


\section{Maturation study}

Seeds were manually sown in expanded polystyrene (Styrofoam) trays, containing commercial substrate, and kept in a greenhouse during emergence and initial seedling development, under controlled irrigation. The mean temperature was $25^{\circ} \mathrm{C} \pm 4{ }^{\circ} \mathrm{C}$ and relative humidity was $60 \% \pm 18 \%$ within the period.

At 25 days after sowing, seedlings with two fully expanded cotyledonary leaves were transplanted to the field and planted in furrows spaced at $0.8 \mathrm{~m}$, keeping 0.6 $\mathrm{m}$ between plants. Crop management practices were applied for adequate plant development and climatic conditions (temperature, rainfall, sunlight, and relative humidity) were monitored daily throughout the phenological plant cycle.

Flowers were labeled at the time of anthesis and four samples of 30 fruits, each selected from the same plant (node) position, were manually harvested at 5-day intervals from five to 65 days after anthesis (DAA) in a completely randomized design. Seeds were extracted immediately after harvest or after a 7-day temporary storage period under laboratory conditions. In both cases, four replicates of each 500 seeds were obtained for each time of harvest and extraction.

The maturation progress was evaluated by determining morphological characteristics of fruits, inner morphology and seed quality parameters, both soon after fruit harvest or after temporary storage.

\section{Physical characteristics of the fruit}

The fruit physical characteristics were represented by the length and diameter in samples comprising 15 fruits at harvest and were evaluated with the aid of a digital caliper rule. Length corresponded to the distance from apex to base of the fruit, and diameter was determined at the basal region of the fruit. Mean results at harvest were expressed in $\mathrm{mm}$ per fruit.

Fruit color was identified through comparison with the Munsell Book of Color (Kollmorgen Corporation, 1976). For that purpose, samples of 15 fruits were evaluated after each harvest, registering the number of fruits corresponding to each color identified and calculating the mean percentage of fruits with the predominant color. The results were expressed as mean percentage of each predominant color, composed by hue, value, and chroma.

Afterwards, fruit samples were photographed using a charge-coupled device (CCD) digital single-lens reflex camera with 2.7 megapixels resolution connected to a computer, using a sensor in the visible spectrum 1370 to $750 \mathrm{~nm}$ ). Fruit samples were positioned perpendicularly at $30 \mathrm{~cm}$ from the lens, without zooming. In order to achieve uniform results, all photos were acquired under the same lighting conditions, avoiding the influence of external light. Lighting was achieved with three 55W fluorescent lights (50 cm in length), $4000 \mathrm{~K}$ color temperature, and a color rendering index (CRI) of approximately $90 \%$. It was used the white balance calibration performed automatically by the camera, and ISO sensitivity of 200 .
The images were analyzed with the aid of Image ${ }^{\circ}$ software to obtain values of intensity of pixels of the red $(R)$, green $(G)$, blue $(B)$, and grey scale components (Gomes-Junior et al., 2017). To obtain these values, an area $(0.60 \times 0.60 \mathrm{~cm})$ in the basal region of the fruit was identified (Figure 1).

\section{Seed water content}

The seed water content was determined by the oven method at $105^{\circ} \mathrm{C} \pm 3^{\circ} \mathrm{C}$ for $24 \mathrm{~h}$ as indicated in the Brazilian Rules for Seed Testing (MAPA, 2009) in four samples of 100 seeds for each harvest time. The results were expressed in mean percentages (fresh weight basis).

\section{Seed dry weight}

Seed dry matter was determined together with the water content at $105 \pm 3{ }^{\circ} \mathrm{C}$. After a 24 -h drying period, the seeds of each replicate were weighed to determine the mean dry matter content (g per 100 seeds).

\section{Germination}

Eight replicates of 25 seeds per harvest time were sown in paper towel rolls moistened with water at 2.5 times the weight of the paper at $30{ }^{\circ} \mathrm{C}$. Seedling evaluations were performed at four (germination first count) and 21 days after sowing (MAPA, 2009). Results were expressed as percentage of normal seedlings per harvest time. At the end of the test, ungerminated seeds (hard or swollen) were submitted to the tetrazolium test to assess their viability as Eichelberger and Moraes (2001). The results were expressed in mean percentage of normal seedlings per harvest time.

\section{Seedling emergence}

Four replicates of 50 seeds for each harvest time were distributed in individual cells of expanded polystyrene (Styrofoam) trays containing a commercial substrate. The trays were then kept in a greenhouse under controlled irrigation (water quantity corresponding to $60 \%$ of the substrate retention capacity). Evaluation was performed at 21 days after sowing, and seedlings

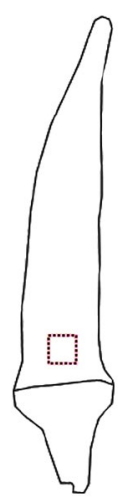

Figure 1 - Representation of the region of okra fruit used for color characterization by means of Image ${ }^{\circledR}$ software. 
with full expansion of cotyledonary leaves above the substrate surface were considered as emerged. The results were expressed as the mean percentage of seedling emergence per harvest time.

\section{X-ray test}

This analysis was performed during seed maturation using the digital Faxitron X-ray, model MX-20 DC12, connected to a Core 2 Duo computer $13.16 \mathrm{GHz}$, 2 GB of RAM, hard disk of $160 \mathrm{~GB}$ ) and 17-inch MultiSync LCD1990SX monitor. Samples of seeds collected at different harvest times were placed at $28.6 \mathrm{~cm}$ from the radiation source and exposed to $28 \mathrm{kV}$ and $1.50 \mathrm{~mA}$ current for $9.7 \mathrm{~s}$.

In order to ensure efficiency of the image analysis to associate seed internal morphology with the occurrence of normal seedlings, abnormal seedlings, and ungerminated seeds, previously numbered X-rayed seeds (to ensure their individual identity) were submitted to the germination test, as described above.

\section{Evaluation of free space in the inner cavity of the seeds and aspect ratio}

Radiographic images of seeds collected at different times ( 8 replicates of 25 seeds per harvest time) were analyzed by Image ${ }^{\circledast}$ software, determining the percentage of free space area in the inner cavity of the seed and the aspect ratio. The percentage of free space (FS) was calculated as follows:

$$
F S=\frac{\text { Free Space Area }}{\text { Inner Cavity Seed Area }} \times 100
$$

where $F S=$ free space (\%), Free Space Area = calculated area of free space $\left(\mathrm{mm}^{2}\right)$ and Inner Cavity Seed Area = calculated area in the inner cavity of the seed $\left(\mathrm{mm}^{2}\right)$.

The aspect ratio (relation between the major and minor axes of the ellipse that circumscribes the seed) was determined by the equation

$$
A R=\frac{\text { Major Axis }}{\text { Minor Axis }}
$$

where $A R=$ aspect ratio index, Major Axis = major axis of the ellipse that circumscribes the seed ( $\mathrm{mm})$ and $M i$ nor Axis = minor axis of the ellipse that circumscribes the seed $(\mathrm{mm})$.

Thus, the seed parts (lighter grey) and the free space between the embryo/endosperm and the seed coat (darker grey) were automatically segmented and quantified by the software, with the results expressed as the aspect ratio index and percentage of free space (Figures $2 \mathrm{~A}$ and B).

\section{Statistical procedure}

A completely randomized scheme was adopted for the field harvest times and a factorial design for each laboratory test comprising the effects of 13 harvest times, two storage periods after each harvest and the interaction of these variables. The data were subjected to analysis of variance and the means were compared by the Tukey test $(p \leq 0.05)$. the statistical analysis was carried out by the SISVAR program (Ferreira, 2000).

\section{Results}

The seed water content right after harvest was $84.4 \%$ at 5 DAA. Subsequent decreases occurred throughout maturation until seeds $(11.0 \%$ to $13.0 \%$ water content) reached hygroscopic equilibrium with relative humidity of air between 50 and 55 DAA. During the temporary storage, there were significant decreases in the seed water content from 5 DAA to 45 DAA (Table 1). In the subsequent harvests (from 50 DAA to 65 DAA), the seed water content was stabilized, reaching values from 10.9 to $12.9 \%$ and did not vary significantly between seeds extracted soon after each harvest and seeds temporarily stored for seven days.

Table 1 - Okra seed water content right after different harvest times during maturation or temporarily stored for seven days after each harvest time.

\begin{tabular}{lcc}
\hline \multirow{2}{*}{ Harvest $\left(\mathrm{DAA}^{*}\right)$} & \multicolumn{2}{c}{ Water Content $(\%)$} \\
\cline { 2 - 3 } 5 & After harvest & Stored \\
10 & $84.4 \mathrm{Aa}$ & $73.2 \mathrm{Ab}$ \\
15 & $87.7 \mathrm{Aa}$ & $74.6 \mathrm{Ab}$ \\
20 & $79.0 \mathrm{Aa}$ & $62.3 \mathrm{Bb}$ \\
25 & $67.2 \mathrm{Ba}$ & $56.1 \mathrm{BCb}$ \\
30 & $60.9 \mathrm{Ca}$ & $50.7 \mathrm{Cb}$ \\
35 & $56.6 \mathrm{CDa}$ & $41.8 \mathrm{Db}$ \\
40 & $49.2 \mathrm{Da}$ & $17.4 \mathrm{~Eb}$ \\
45 & $31.0 \mathrm{Ea}$ & $14.9 \mathrm{EFb}$ \\
50 & $25.0 \mathrm{Ea}$ & $13.2 \mathrm{Fb}$ \\
55 & $12.9 \mathrm{Fa}$ & $12.8 \mathrm{Fa}$ \\
60 & $11.6 \mathrm{Fa}$ & $11.6 \mathrm{Fa}$ \\
65 & $11.0 \mathrm{Fa}$ & $11.1 \mathrm{Fa}$ \\
\hline
\end{tabular}

${ }^{*}$ DAA = days after anthesis; uppercase letters mean comparison within each column; lowercase letters mean comparison within each row for each parameter (Tukey test, $p \leq 0.01$ ).
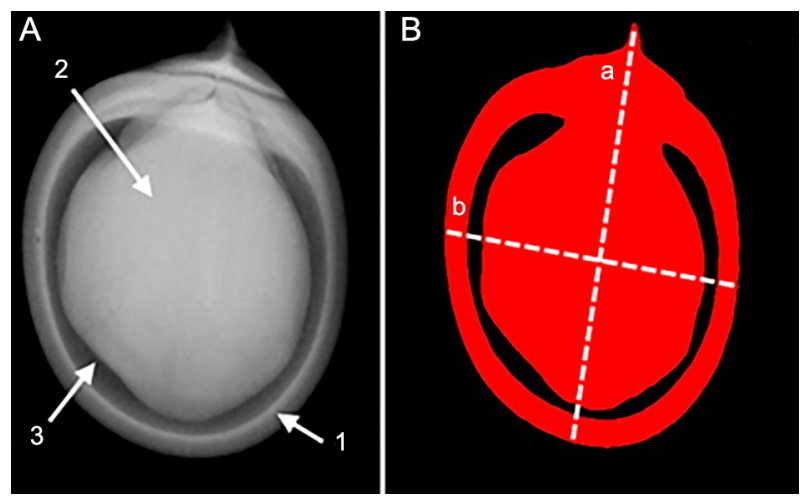

Figure 2 - X-ray images of okra seed (A) with identification of the seed coat (1), embryo (2), and free inner space (3) and respective image segmented by Image $J^{\circledR}$ software (B) with representation of aspect ratio determination $(\mathrm{a} / \mathrm{b})$. 
At the same time, the seed dry weight increased, reaching the maximum at $30 \mathrm{DAA}$. There was statistically significant variation between dry matter of seeds extracted immediately after each harvest and those temporarily stored from $5 \mathrm{DAA}$ to $20 \mathrm{DAA}$. In the subsequent harvests, from 20 to $35 \mathrm{DAA}$, the mean values of seed dry weight from the stored seeds tended to increase, but not statistically significant (Table 2). Seed dry matter reached the maximum and was stabilized from 30 DAA harvest times.

The statistical analysis showed significant differences for fruit length and diameter throughout the maturation period (Table 2). Fruit elongation rate was more evident at the beginning of the development (from 15 to $25 \mathrm{DAA}$ ) and maximum length was identified at 45 DAA. The increase in diameter did not follow this same pattern as the maximum value was identified at $25 \mathrm{DAA}$, followed by decreases in subsequent harvest times. Significant differences were not found between these parameters in recently harvested fruits in comparison to those temporarily stored for seven days.

Germination varied significantly during maturation and the effects of harvest times, storage periods, and the interaction of these factors were significant. Seeds extracted right after harvest did not germinate until 25 DAA and then increased significantly, reaching a maximum at 50 DAA (Table 1). Germination of seeds temporarily stored was detected from 20 DAA and then increased until reaching the maximum at 50 DAA. In general, germination of seeds collected from 40 DAA tended to stabilize, both for seeds extracted soon after each harvest and for those temporarily stored. There was practically no occurrence of hard seeds, as indicated by the tetrazolium test results (data not shown).

There was no manifestation of seed vigor in recently extracted seeds, expressed by germination first count, until 25 DAA, and then increased from 30 DAA, reaching the maximum at $50 \mathrm{DAA}$. This also occurred for the seedling emergence percentage (Table 2). In general, seedling emergence from stored seeds started from harvest at $20 \mathrm{DAA}$, that is, later than observed for not stored seeds (30 DAA). The values of germination first count and in seedling emergence from stored seeds were higher than those from seeds extracted right after each harvest.

Visual analyses performed by comparison with the Munsell color charts allowed identification of a defined sequence of fruit color changes throughout maturation. We identified fruits of moderate yellow green (7.5GY $8 / 6$ or $8 / 8$ ), yellowish bright brown (7.5YR 7/4), and bright brown (7.5YR 6/4). From 5 to 25 DAA, there was prevalence of moderate yellow green fruit color, when yellowish bright brown fruits arose, representing $40 \%$ of the total (Table 3). The percentages of bright brown fruit increased up to $50 \mathrm{DAA}$ as the moderate yellow green fruits declined. At $60 \mathrm{DAA}$, especially at 65 DAA, the bright brown fruit became more evident and there were no longer moderate yellow green fruits. At 30 DAA, when seeds achieved maximum dry matter, around $73 \%$ of the fruits showed yellowish bright brown color, and at $50 \mathrm{DAA}$, upon reaching maximum physiological potential, this percentage reached $80 \%$.

The visually evaluated fruit color was also identified by determining the RGB composition and grey scale. Differences were detected even in fruits of the same color identified by the Munsell chart during maturation (Figure 3). Thus, based on the histograms of pixel intensity, the individual color components indicated that up to 20 DAA (moderate yellow green fruit - 7.5 GY), there was predominance of the G component, followed by $R$, whereas the fruit had reduced concentrations of the B component.

Table 2 - Okra fruit length and diameter, seed dry matter, water content, total germination, germination first count, and seedling emergence from fruits harvested at different times during maturation and temporarily stored or not for seven days after each harvest time.

\begin{tabular}{|c|c|c|c|c|c|c|c|c|c|c|}
\hline \multirow{2}{*}{ Harvest (DAA*) } & \multirow{2}{*}{ Fruit Length } & \multirow{2}{*}{ Fruit Diameter } & \multicolumn{2}{|c|}{ Dry matter (g 100 seed $^{-1}$ ) } & \multicolumn{2}{|c|}{ Germination (\%) } & \multicolumn{2}{|c|}{ Germination First Count (\%) } & \multicolumn{2}{|c|}{ Seedling Emergence (\%) } \\
\hline & & & After harvest & Stored & After harvest & Stored & After harvest & Stored & After harvest & Stored \\
\hline & $-n$ & $\mathrm{~m}$ & & & & & & & & \\
\hline 5 & $70.9 \mathrm{C}$ & $13.0 \mathrm{CD}$ & $0.05 \mathrm{Db}$ & $0.06 \mathrm{Ea}$ & $0 \mathrm{Da}$ & $0 \mathrm{Ea}$ & $\mathrm{OFa}$ & $0 \mathrm{Ea}$ & $\mathrm{OHa}$ & $\mathrm{OHa}$ \\
\hline 10 & $170.1 \mathrm{~B}$ & $19.6 \mathrm{~B}$ & $0.50 \mathrm{CDb}$ & $0.91 \mathrm{Da}$ & $0 \mathrm{Da}$ & $0 \mathrm{Ea}$ & $0 \mathrm{Fa}$ & $0 \mathrm{Ea}$ & $\mathrm{OHa}$ & $\mathrm{OHa}$ \\
\hline 15 & $198.2 \mathrm{~A}$ & $20.2 A B$ & $0.86 \mathrm{Cb}$ & $2.50 \mathrm{Ca}$ & $0 \mathrm{Da}$ & $0 \mathrm{Ea}$ & $0 \mathrm{Fa}$ & $0 \mathrm{Ea}$ & $\mathrm{OHa}$ & $\mathrm{OHa}$ \\
\hline 20 & $196.3 \mathrm{AB}$ & $21.5 \mathrm{AB}$ & $3.90 \mathrm{Ba}$ & $4.18 \mathrm{Ba}$ & $0 \mathrm{Db}$ & $24 \mathrm{Da}$ & $0 \mathrm{Fb}$ & $3 \mathrm{Ea}$ & $\mathrm{OHb}$ & $25 \mathrm{Ga}$ \\
\hline 25 & $195.8 \mathrm{AB}$ & $22.1 \mathrm{~A}$ & 4.34 Ba & $4.50 \mathrm{Ba}$ & $0 \mathrm{Db}$ & $54 \mathrm{Ca}$ & $0 \mathrm{Fb}$ & $7 \mathrm{Da}$ & $\mathrm{OHb}$ & $47 \mathrm{Ea}$ \\
\hline 30 & $192.2 A B$ & $20.5 \mathrm{AB}$ & $5.39 \mathrm{Aa}$ & $5.32 \mathrm{Aa}$ & $44 \mathrm{Cb}$ & $51 \mathrm{Ca}$ & $8 \mathrm{~Eb}$ & $19 \mathrm{Ca}$ & $36 \mathrm{Ga}$ & $46 \mathrm{Fa}$ \\
\hline 35 & $185.7 \mathrm{AB}$ & $20.3 \mathrm{AB}$ & $5.42 \mathrm{Aa}$ & $5.49 \mathrm{Aa}$ & $76 \mathrm{Ba}$ & $78 \mathrm{ABa}$ & $13 \mathrm{Db}$ & $22 \mathrm{Ca}$ & $87 \mathrm{Cb}$ & $96 \mathrm{Aa}$ \\
\hline 40 & $189.0 \mathrm{AB}$ & $13.6 \mathrm{C}$ & $5.64 \mathrm{Aa}$ & $5.65 \mathrm{Aa}$ & $78 \mathrm{ABb}$ & $85 \mathrm{Aa}$ & $24 \mathrm{Cb}$ & $33 \mathrm{Ba}$ & $81 \mathrm{Db}$ & $90 \mathrm{Ba}$ \\
\hline 45 & $204.7 \mathrm{~A}$ & 12.2 CDE & $5.64 \mathrm{Aa}$ & $5.58 \mathrm{Aa}$ & $73 \mathrm{Bb}$ & $86 \mathrm{Aa}$ & $26 \mathrm{BCb}$ & $31 \mathrm{Ba}$ & $92 \mathrm{Bb}$ & $100 \mathrm{Aa}$ \\
\hline 50 & $189.4 \mathrm{AB}$ & 12.0 CDE & $5.45 \mathrm{Aa}$ & $5.67 \mathrm{Aa}$ & $85 \mathrm{Ab}$ & $94 \mathrm{Aa}$ & $34 \mathrm{Ab}$ & $38 \mathrm{Aa}$ & $100 \mathrm{Aa}$ & $98 \mathrm{Aa}$ \\
\hline 55 & $192.5 \mathrm{AB}$ & $10.7 \mathrm{E}$ & $5.46 \mathrm{Aa}$ & $5.57 \mathrm{Aa}$ & $85 \mathrm{Ab}$ & $91 \mathrm{Aa}$ & $28 \mathrm{Bb}$ & $31 \mathrm{Ba}$ & $75 \mathrm{~Eb}$ & $87 \mathrm{BCa}$ \\
\hline 60 & $197.6 \mathrm{~A}$ & 11.3 DE & $5.41 \mathrm{Aa}$ & $5.41 \mathrm{Aa}$ & $84 \mathrm{Aa}$ & $83 \mathrm{Ba}$ & $24 \mathrm{Cb}$ & $30 \mathrm{Ba}$ & $58 \mathrm{Fb}$ & $83 \mathrm{Ca}$ \\
\hline 65 & $194.4 \mathrm{AB}$ & 12.6 CDE & $5.33 \mathrm{Aa}$ & $5.41 \mathrm{Aa}$ & $78 \mathrm{ABb}$ & $84 \mathrm{Aba}$ & $24 \mathrm{Cb}$ & $31 \mathrm{Ba}$ & $60 \mathrm{Fb}$ & $87 \mathrm{BCa}$ \\
\hline
\end{tabular}

${ }^{*} \mathrm{DAA}=$ days after anthesis; uppercase letters mean comparison within each column; lowercase letters mean comparison within each row for each parameter (Tukey test, $p \leq 0.01$ ). 
Table 3 - Predominant color of okra fruit harvested at different times after anthesis.

\begin{tabular}{|c|c|c|c|}
\hline \multirow{2}{*}{$\begin{array}{l}\text { Harvest } \\
\text { DAA* }^{*}\end{array}$} & \multicolumn{3}{|c|}{ Fruit Color } \\
\hline & Identification & Percentage & Hue Value Chroma \\
\hline \multirow{2}{*}{5} & \multirow{2}{*}{ Moderate yellow green } & 60.0 & $7.5 \mathrm{GY} 8 / 8$ \\
\hline & & 40.0 & $7.5 \mathrm{GY} 8 / 6$ \\
\hline \multirow{2}{*}{10} & \multirow{2}{*}{ Moderate yellow green } & 67.0 & $7.5 \mathrm{GY} 8 / 6$ \\
\hline & & 33.0 & $7.5 \mathrm{GY} 8 / 8$ \\
\hline \multirow{2}{*}{15} & \multirow{2}{*}{ Moderate yellow green } & 53.0 & $7.5 \mathrm{GY} 8 / 6$ \\
\hline & & 47.0 & $7.5 \mathrm{GY} 8 / 8$ \\
\hline \multirow{2}{*}{20} & \multirow{2}{*}{ Moderate yellow green } & 73.0 & $7.5 \mathrm{GY} 8 / 6$ \\
\hline & & 27.0 & 7.5 GY 8/8 \\
\hline \multirow{3}{*}{25} & \multirow{2}{*}{ Moderate yellow green } & 53.0 & 7.5 GY $8 / 6$ \\
\hline & & 7.0 & $7.5 \mathrm{GY} 8 / 8$ \\
\hline & Yellowish bright brown & 40.0 & 7.5 YR $7 / 4$ \\
\hline \multirow{2}{*}{30} & Yellowish bright brown & 73.0 & 7.5 YR 7/4 \\
\hline & Moderate yellow green & 27.0 & 7.5 GY $8 / 6$ \\
\hline \multirow{2}{*}{35} & Yellowish bright brown & 80.0 & 7.5 YR 7/4 \\
\hline & Moderate yellow green & 20.0 & $7.5 \mathrm{GY} 8 / 6$ \\
\hline \multirow{2}{*}{40} & Yellowish bright brown & 73.0 & 7.5 YR 7/4 \\
\hline & Moderate yellow green & 27.0 & 7.5 GY 8/6 \\
\hline \multirow{2}{*}{45} & Yellowish bright brown & 80.0 & 7.5 YR $7 / 4$ \\
\hline & Moderate yellow green & 20.0 & $7.5 \mathrm{GY} 8 / 6$ \\
\hline \multirow{2}{*}{50} & Yellowish bright brown & 80.0 & 7.5 YR $7 / 4$ \\
\hline & Moderate yellow green & 20.0 & $7.5 \mathrm{GY} 8 / 6$ \\
\hline \multirow{3}{*}{55} & Yellowish bright brown & 53.0 & 7.5 YR 7/4 \\
\hline & Moderate yellow green & 33.0 & $7.5 \mathrm{GY} 8 / 6$ \\
\hline & Bright brown & 14.0 & 7.5YR 6/4 \\
\hline \multirow{2}{*}{60} & Yellowish bright brown & 67.0 & 7.5 YR $7 / 4$ \\
\hline & Bright brown & 33.0 & 7.5YR 6/4 \\
\hline \multirow{2}{*}{65} & Bright brown & 87.0 & 7.5YR 6/4 \\
\hline & Yellowish bright brown & 13.0 & 7.5 YR $7 / 4$ \\
\hline
\end{tabular}

${ }^{*} \mathrm{DAA}=$ days after anthesis.

From 20 DAA onward, there were increases in the $\mathrm{B}$ component as the percentage of yellowish bright brown fruit increased. The proportions of the $\mathrm{R}$ and $\mathrm{G}$ components were similar from 45 DAA harvest time, with R slightly higher up to 65 DAA. Simultaneously, the grey scale practically stabilized.

The variation of intensity of the pixels in each band showed a colorimetric distinction between data

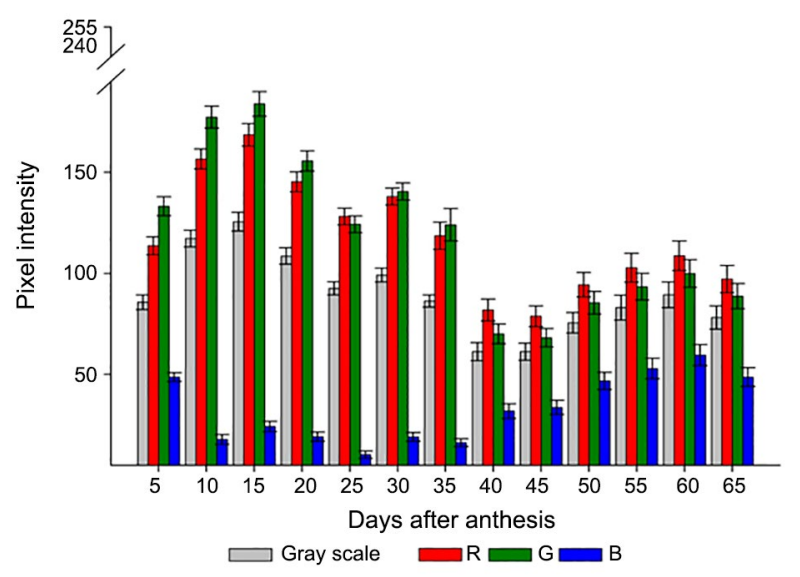

Figure 3 - Values of pixel intensity for each component of red (R), green $(G)$, and blue $(B)$ color and grey scale for okra fruit color right after each harvest time; bars indicate \pm mean standard error.

from 35 to 40 DAA. This may be an interesting period for the colorimetric aspect of fruits that may be associated with physiological attributes thus allowing to detect, for example, the optimal period for harvest. This result may also constitute a basis for the development of an automated procedure to distinguish fruit classes according to maturation stage and seed performance.

Regarding evaluation of seed internal morphology and its association with germination, variations were detected in the presence of empty, poorly formed, or full seeds during maturation (Table 4). Thus, in seeds extracted immediately after each harvest, normal seedlings were not found up to $25 \mathrm{DAA}$, when the mean free space was higher than $18 \%$. Conversely, seeds extracted after temporary storage produced normal seedlings at $20 \mathrm{DAA}$. In the subsequent harvest times, there were progressive increases in the formation of normal seedlings and decreases in the occurrence of ungerminated seeds. In general, seeds temporarily stored after each harvest originated higher percentages of normal seedlings from 20 to 50 DAA, while the percentages of abnormal seedlings remained relatively stable.

There were significant effects of the maturation stage on the proportion of free space in evaluations of seed inner cavity and aspect ratio; however, there was no influence of the interaction harvest time $\times$ storage period. At the initial stages of maturation $(5$ and 10 DAA), free space represented practically the entire inner seed cavity (Table 5); however, from 15 DAA, there were significant decreases up to 30 DAA and these values practically stabilized around $1 \%$ from 50 DAA, when it was identified the maximum seed physiological potential (germination and vigor).

There were also variations in the aspect ratio indices throughout maturation (Table 5), with maximum values occurring at $5 \mathrm{DAA}$ and $10 \mathrm{DAA}$, reducing at later harvest times, when the indices stabilized at 1.1 . 
Table 4 - Relationship between X-ray images and percentage of occurrence of normal seedlings, abnormal seedlings, and dead seeds during maturation of okra seeds.

\begin{tabular}{|c|c|c|c|c|c|}
\hline \multirow[b]{2}{*}{$\begin{array}{l}\text { Harvest } \\
\text { DAA }^{*}\end{array}$} & \multirow[b]{2}{*}{ X-Rays } & \multirow[b]{2}{*}{$\begin{array}{c}\text { Storage } \\
\text { (days) }\end{array}$} & NS & AS & DS \\
\hline & & & & (7) & \\
\hline \multirow{2}{*}{5} & & 0 & 0 & 0 & 100 \\
\hline & & 7 & 0 & 0 & 100 \\
\hline \multirow{2}{*}{10} & & 0 & 0 & 0 & 100 \\
\hline & & 7 & 0 & 0 & 100 \\
\hline \multirow{2}{*}{15} & & 0 & 0 & 0 & 100 \\
\hline & & 7 & 0 & 0 & 100 \\
\hline \multirow{2}{*}{20} & & 0 & 0 & 0 & 100 \\
\hline & & 7 & 20 & 36 & 36 \\
\hline \multirow{2}{*}{25} & & 0 & 0 & 0 & 100 \\
\hline & & 7 & 51 & 19 & 12 \\
\hline \multirow{2}{*}{30} & & 0 & 31 & 16 & 41 \\
\hline & & 7 & 44 & 12 & 33 \\
\hline \multirow{2}{*}{35} & & 0 & 52 & 20 & 7 \\
\hline & & 7 & 72 & 21 & 19 \\
\hline \multirow{2}{*}{40} & & 0 & 76 & 12 & 9 \\
\hline & & 7 & 80 & 17 & 3 \\
\hline \multirow{2}{*}{45} & & 0 & 69 & 12 & 17 \\
\hline & & 7 & 81 & 18 & 1 \\
\hline \multirow{2}{*}{50} & & 0 & 80 & 20 & 0 \\
\hline & & 7 & 89 & 10 & 0 \\
\hline \multirow{2}{*}{55} & & 0 & 83 & 15 & 2 \\
\hline & & 7 & 85 & 14 & 0 \\
\hline \multirow{2}{*}{60} & & 0 & 82 & 17 & 0 \\
\hline & & 7 & 78 & 18 & 0 \\
\hline \multirow{2}{*}{65} & & 0 & 75 & 16 & 0 \\
\hline & & 7 & 71 & 12 & 0 \\
\hline
\end{tabular}

${ }^{*} \mathrm{DAA}=$ days after anthesis; $\mathrm{NS}=$ normal seedlings; $\mathrm{AS}=$ abnormal seedlings; DS $=$ dead seeds.
Table $\mathbf{5}$ - Variation of free space in the inner cavity of seeds and aspect ratio during maturation of okra seeds.

\begin{tabular}{|c|c|c|c|c|}
\hline \multirow{2}{*}{ Harvest DAA* } & \multicolumn{2}{|c|}{ Free Space (\%) } & \multicolumn{2}{|c|}{ Aspect ratio (index) } \\
\hline & Non stored & Stored 7 days & Non stored & Stored 7 days \\
\hline 5 & $99.7 \mathrm{Aa}$ & $99.9 \mathrm{Aa}$ & $1.4 \mathrm{~A}$ & $1.4 \mathrm{~A}$ \\
\hline 10 & $100.0 \mathrm{Aa}$ & $99.7 \mathrm{Aa}$ & $1.4 \mathrm{~A}$ & $1.4 \mathrm{~A}$ \\
\hline 15 & $19.6 \mathrm{Ba}$ & $21.1 \mathrm{Ba}$ & $1.2 \mathrm{~B}$ & $1.2 \mathrm{~B}$ \\
\hline 20 & 18.0 Ba & $14.0 \mathrm{Cb}$ & $1.1 \mathrm{~B}$ & $1.2 \mathrm{~B}$ \\
\hline 25 & $8.0 \mathrm{Ca}$ & 9.4 Da & $1.2 \mathrm{~B}$ & $1.1 \mathrm{BC}$ \\
\hline 30 & 3.6 Da & $4.9 \mathrm{Ea}$ & $1.1 \mathrm{~B}$ & $1.1 \mathrm{~B}$ \\
\hline 35 & 2.7 Da & 2.0 EFa & $1.1 \mathrm{~B}$ & $1.1 \mathrm{~B}$ \\
\hline 40 & $3.4 \mathrm{Db}$ & $1.5 \mathrm{EFa}$ & $1.1 \mathrm{~B}$ & $1.1 \mathrm{~B}$ \\
\hline 45 & $2.2 \mathrm{Da}$ & 2.4 EFa & $1.1 \mathrm{~B}$ & $1.2 \mathrm{~B}$ \\
\hline 50 & $1.3 \mathrm{Da}$ & $0.8 \mathrm{Fa}$ & $1.1 \mathrm{~B}$ & $1.1 \mathrm{BC}$ \\
\hline 55 & $1.5 \mathrm{Da}$ & $1.6 \mathrm{Fa}$ & $1.1 \mathrm{~B}$ & $1.2 \mathrm{~B}$ \\
\hline 60 & $1.9 \mathrm{Da}$ & 2.2 EFa & $1.1 \mathrm{~B}$ & $1.1 \mathrm{BC}$ \\
\hline 65 & $0.6 \mathrm{Da}$ & $1.6 \mathrm{Fa}$ & $1.1 \mathrm{~B}$ & $1.1 \mathrm{BC}$ \\
\hline
\end{tabular}

${ }^{*} \mathrm{DAA}=$ days after anthesis; uppercase letters mean comparison within each column; lowercase letters mean comparison within each row for each parameter (Tukey test, $p \leq 0.01$ ).

\section{Discussion}

The okra crop is mainly adapted to tropical and subtropical regions and develops better under relatively high temperatures, from 18 to $30{ }^{\circ} \mathrm{C}$. In this study, plants developed under favorable climatic conditions, that is, mean temperatures from 20 to $30{ }^{\circ} \mathrm{C}$, and adequate rains distributed throughout vegetative growth, flowering, and maturation; thus, supplemental irrigation was not necessary.

Knowledge of the maturation process is important from the biological viewpoint and for accurate identification of physiological maturity to determine the most adequate harvest time of economically important species. In the specific case of okra, a species with an indeterminate growth habit and lack of uniformity of flowering and maturation, split harvest is recommended as the fruit maturates to obtain seeds of greater physiological potential (Setubal and Nascimento, 2014). In species of indeterminate growth habit, which seeds produced in fleshy fruits, such as okra, it is recommended to perform early harvests (near physiological maturity) followed by temporary storage of fruits to complete the maturation process (Dias et al., 2006).

In this study, fruit length continued to increase until 45 DAA, and decreased only when dehydration became more accentuated. In addition, the most evident reduction in diameter occurred together with fruit drying (49 to $31 \%$ water content). Variations of fruit length and diameter during maturation were not associated to other morph- and physiological parameters, including seed maximum dry matter; therefore, they did not constitute efficient markers of physiological maturity, as emphasized by Carvalho (2014).

Maximum accumulation of dry matter occurred when the seed water content was relatively high 
(56.6\%), at $30 \mathrm{DAA}$, which is compatible to the water content described for dicotyledonous seeds (Marcos-Filho, 2016). The presence of a sufficient amount of water is necessary to support the movement of solutes (primarily photosynthates and minerals) from the plant to seeds and the consequent dry matter accumulation. There was significant variation in the dry matter of seeds stored temporarily, in comparison to seeds extracted right after harvest, from 5 to $15 \mathrm{DAA}$, when seeds had initial water content from 84.4 to $79.0 \%$. In the subsequent harvests, non-significant increases occurred from 25 to 35 DAA, indicating the absence of reserve transference from the fruit to seeds during the post-harvest fruit-resting period. The transference of dry matter to seeds during the temporary storage was more evident in seeds with higher water content (over $80.0 \%$ ), in the three first harvests and became non-significant from 20 to 35 DAA, when seeds reached the maximum dry weight. This indicates that it is possible to perform early harvests (before physiological maturity) followed by a temporary storage of fruits as an alternative to obtain seeds of high physiological potential.

The occurrence of increases in dry matter during this temporary storage period due to the continuity of transfer of fruit reserves from fleshy fruits to seeds during the temporary storage after harvest was reported by Dias et al. (2006), Vidigal et al., 2009, and Dias (2009). The possible variation in the transference of dry matter during temporary storage of fruit is influenced by the species, maturation stage at harvest, conditions and period of storage (Demir and Ellis, 1992).

Germination was higher than the minimum standard $(70 \%)$ established for okra seed marketing in Brazil, from harvests at $35 \mathrm{DAA}$, reaching the maximum value at 50 DAA, when most fruits were yellowish bright brown and germination first count and seedling emergence also achieved the maximum. These values occurred after the time when seeds achieved maximum dry matter (30 DAA), a usual characteristic of seeds produced in fleshy fruits (Demir and Ellis, 1992; TeKrony and Egli, 1997; Vidigal et al., 2006; Silva et al., 2015).

Seeds temporarily stored after harvest were able to germinate ten days earlier (20 DAA) than those extracted immediately after harvest (30 DAA). Seed ability to withstand desiccation increases progressively during maturation. At the initial stages, seeds are able to withstand desiccation only when they are slowly dehydrated while still attached to the parent plant. In this situation, protective mechanisms are activated that provide greater tolerance to cell imbalances caused by fast dehydration. In contrast, at the end of maturation, when most reserves have been deposited, seeds not only become more tolerant to desiccation, but also exhibit a greater capacity to germinate rapidly and form normal seedlings (Bewley et al., 2013; Marcos-Filho, 2016). The intolerant phase is manifested during the phases of cell division and expansion and most of the reserve transference period from the parent plant. The seed can significantly tolerate desiccation during maturation when most reserves have already been deposited (Vertucci and Farrant, 1995; Kermode and Finch-Savage, 2002). Probably, for that reason, okra seeds extracted from fruits up to 30 DAA and dried rapidly did not tolerate desiccation and did not germinate, in contrast to seeds temporarily stored in the fruit and slowly dehydrated.

The degree of seed tolerance to desiccation is directly related to the capacity of cells to keep integrity of their membranes and prevent denaturation of proteins (Decker et al., 2015). If drying is relatively slow, in seeds still attached to the fruit, there may be enough time for adjustments to keep integrity of cell structure, as occurred in this study.

Rapid and premature desiccation affects synthesis of proteins and essential enzymes for seed development and germination. Desiccation favors the normal route of protein and enzyme synthesis and allows organization of the cell membrane system. Removal of seeds from the plant during the initial stages of maturation may lead to complete loss of viability (Bewley et al., 2013).

Post-harvest temporary storage was beneficial to seed germination and vigor. This fact has been reported for various species that produce fleshy fruits (Vidigal et al., 2006; Araujo et al., 2007; Silva et al., 2015). The absence of significant variations in seed dry matter, mostly during the temporary rest period, may increase the physiological potential that are attributed to metabolic adjustments (Dias, 2009; Bewley et al., 2013).

In this sense, Villiers and Edgcumbe (1975) showed that seeds with a hydration level near complete imbibition (as is the case of seeds that remain within fleshy fruits) are able to keep viability for a long period. The authors suggested that this occurs due to the action of repair mechanisms of damages that may accumulate during storage. This hypothesis can explain the higher physiological potential of seeds temporarily stored in fleshy fruits after harvest.

Okra seeds may show lack of uniformity or absence of germination because of the occurrence of seed coat impermeability to water (Setubal and Nascimento, 2014), whose formation is induced by the occurrence of moderate water deficit during maturation (Marcos-Filho, 2016). Although the cv. Santa Cruz 47 generally produces a significant quantity of hard seeds, this was not observed here because water availability and its distribution during maturation were sufficient to not induce dormancy.

Fruit color was determined through comparison with the Munsell Book of Color that allowed a visual perception of the color variation of fruits during maturation. The precise and mathematical comparison was improved by quantifying RGB and grey scale.

Variation in fruit color followed a defined sequence of colors from moderate yellow green to yellowish bright brown and to bright brown was identified. The percentages of bright brown fruits increased as the percentages of yellow green fruits decreased and yellow green fruit color was no longer observed at 60 DAA and 65 DAA. At 
the time of physiological maturity (30 DAA), there was $73 \%$ of yellowish bright brown (7.5 YR) fruits, while this color accounted for $80 \%$ of the total at 50 DAA. This indicates that fruit color constitutes a marker for monitoring the maturation process of okra seeds and for identifying the time when seeds reach maximum dry weight and physiological potential.

Color is one of the most important visual physical parameters of various fruit species, including vegetable crops, and can be evaluated automatically using different computer visual systems (Pathare et al., 2013). Evaluation by the RGB color system to characterize different okra ripening stages confirmed this possibility by detecting significant changes in the pixel intensity of the $R$ and $\mathrm{G}$ components, corresponding to the fruit maturity degree and then improving the information provided by the visual analysis based on the Munsell color chart. As an example, the analysis of the RGB intensity and gray scale showed a colorimetric threshold between 35 and 40 DAAD, indicating an important period during fruit maturation, possibly associated to intense physiological variations. This procedure represents an important technological evolution, allowing to reduce human influence to identify different fruit ripening stages and improve accuracy of this analysis.

Analyses of X-ray images detected the beginning of germination at 20 DAA (fruits temporarily stored) and at 30 DAA (seeds extracted right after harvest), confirming the results of the germination tests. Thus, normal seedlings formed only when the area corresponding to the free space in the seed was less than $14 \%$. The successive increase in percentages of normal seedlings during the maturation period followed the same tendency already detected for germination and vigor tests.

Increases in the free space area in the seed indicate insufficient embryo development, reflecting poor seed formation. The relation between the degree of embryo development and seed viability was also identified by Dell'Aquilla (2009), Gagliardi and Marcos-Filho (2011), and Silva et al. (2015). However, clarification whether the embryo size has a direct association with seed physiological potential is needed, as questioned by Gomes-Junior (2010).

In this study, when the seeds reached physiological maturity (at $35 \mathrm{DAA}$ ), the area corresponding to free space in the seed was $\leq 5 \%$ and, when the maximum physiological potential was attained (50 DAA), the free space was smaller than $1 \%$. This means that reduction in free space corresponds to increases in seed germination and vigor. However, this is only one of the factors that affect germination, if availability of water and oxygen, temperature, and the balance of promoting and inhibiting substances are not limiting (Nonogaki et al., 2006). During maturation, seeds exhibited morphological changes, successively becoming more spherical and reaching an aspect ratio nearer 1.0, indicating similarity between the major and minor axes of the ellipse surrounding the seed perimeter. There was no tendency for variation in this parameter after $15 \mathrm{DAA}$, indicating that the seeds assumed a practically spherical shape at physiological maturity and then stabilized. The importance of determining the roundness degree was corroborated by Wendt et al. (2014).

Thus, the use of computerized visual resources confirms the possibility of developing efficient and nondestructive tools to improve evaluation of okra seed physiological potential and contribute to composition of more efficient quality control programs. The results obtained allow to conclude that accurate determinations of fruit color, of the area corresponding to free space in the inner seed cavity, and of seed roundness constitute efficient markers for monitoring okra seed maturation. Nevertheless, without sufficient knowledge of seed morphology, these analyses cannot be consistently performed and results cannot be interpreted correctly.

\section{Acknowledgement}

The CNPq (Conselho Nacional de Desenvolvimento Científico e Tecnológico) and CAPES Foundation (Coordenação de Aperfeiçoamento de Pessoal de Nível Superior) are acknowledged for providing financial support in this research. Appreciation is extended to Dr. Warley M. Nascimento from Embrapa Hortaliças for his important technical support.

\section{Authors' Contributions}

Conceptualization: Marcos-Filho, J.; Gomes-Junior, F,G.; Santos, R.F. Data acquisition: Santos, R.F.; Gomes-Junior, F.G.; Marcos-Filho, J. Data analysis: Santos, R.F.; Gomes-Junior, F.G.; Marcos-Filho, J. Design of methodology: Marcos-Filho, J.; Gomes-Junior, F.G.; Santos, R.F. Writing and editing: Marcos-Filho, J.; Santos, R.F.; Gomes-Junior, F.G.

\section{References}

Araujo, E.C.; Silva, R.F.; Viana, A.P.; Silva, M.V. 2007. Degree of maturation and storage on seed quality of passionfruits. Revista Brasileira de Sementes 29: 60-67 (in Portuguese, with abstract in English).

Bewley, J.D.; Bradford, K.; Hilhorst, H.W.M.; Nonogaki, H. 2013. Seeds: Physiology of Development, Germination and Dormancy. 3ed. Springer, New York, NY, USA.

Carvalho, C. 2014. Bell pepper fruit maturation and morphoanatomical, physiological and biochemical characterization of the seeds. (Thesis - Doctorate) - University of São Paulo, São Paulo, SP, Brazil (in Portuguese, with abstract in English).

Chamma, H.M.C.P.; Marcos-Filho, J.; Crocomo, O.J. 1990. Maturation of seeds of 'Aroana" beans and its influence on storage potential. Seed Science and Technology 18: 371-382.

Decker, J.W.; Costa, M.C.D.; Maia, J.; Ligterink, W.; Hilhorst, H.W.M. 2015. Acquisition and loss of desiccation tolerance in seeds: from experimental model to biological relevance. Planta 241: 563-577. 
Dell'Aquilla, A. 2009. Development of novel techniques in conditioning, testing and sorting seed physiological quality. Seed Science and Technology 37: 608-624.

Delouche, J.C. 1971. Seed Maturation. Mississippi State University, State College, MS, USA. (Handbook of Seed Technology).

Demir, I.; Ellis, R.H. 1992. Changes in seed quality during seed development and maturation in tomato. Seed Science Research 2: 81-87.

Dias, D.C.F.S. 2009. Vegetable seed development, maturation and harvest $=$ Desenvolvimento, maturação e colheita de sementes de hortaliças. p. 11-74. In: Nascimento, W.M., ed. Vegetable seed technology $=$ Tecnologia de sementes de hortaliças. Embrapa Hortaliças, Brasília, DF, Brazil (in Portuguese).

Dias, D.C.F.S.; Ribeiro, F.P.; Dias, L.A.S.; Silva, D.J.H.; Vidigal, D.S. 2006. Tomato seed quality in relation to fruit maturation and post-harvest storage. Seed Science and Technology 34: 691699.

Eichelberger, L.; Moraes, D.M. 2001. Preconditioning of okra (Abelmoschus esculentus (L.) Moench) seeds for the tetrazolium test $=$ Preparo de sementes de quiabo (Abelmoschus esculentus (L.) Moench) para o teste tetrazólio. Revista Brasileira de Sementes 23: 154-158 (in Portuguese).

Ferreira, D.F. 2000. Statistical analysis by SISVAR for Windows, version $4.0=$ Análises estatísticas por meio do SISVAR para Windows versão 4.0. p. 255-258. In: International Biometry Society Annual Meeting, 45 = Reunião Anual da Região Brasileira da Sociedade internacional de Biometria. São Carlos, UFSCAR, Brazil (in Portuguese).

Gagliardi, B.; Marcos-Filho, J. 2011. Relationship between germination and bell pepper seed structure assessed by the X-ray test. Scientia Agricola 38: 411-416.

Gomes-Junior, F.G. 2010. Application of image analysis for evaluation of seed morphology = Aplicação da análise de imagens para avaliação da morfologia interna de sementes. Informativo Abrates 20: 33-39 (in Portuguese).

Gomes-Junior, F.G.; Arruda, N.; Marcos-Filho, J. 2017. Swingle citrumelo seed vigor and storability associated with fruit maturity classes based on RGB parameters. Scientia Agricola 74: 357-363.

Kermode, A.R.; Finch-Savage, B.E. 2002. Desiccation sensitivity in orthodox and recalcitrant seeds in relation to development. p. 149-184. In: Black, M.; Pritchard, H.W., eds. Desiccation and survival in plants: drying without dying. CABI International, Wallingford, UK.

Kollmorgen Corporation. 1976. Munsell Book of Color. Neighboring Hues Edition, Baltimore, MD, USA.

Marcos-Filho, J. 1980. Physiological maturity of soybean seeds. Pesquisa Agropecuária Brasileira 15: 447-460 (in Portuguese, with abstract in English).

Marcos-Filho, J. 2016. Seed Physiology of Cultivated Plants. Abrates, Londrina, PR, Brazil.

Ministério da Agricultura, Pecuária e Abastecimento [MAPA]. 2009. Rules for seed testing = Regras para Análise de Sementes. MAPA-SDA, Brasília, DF, Brazil (in Portuguese).
Nascimento, W.M.; Lima, L.B.; Alvares, M.C. 2000. Eggplant hybrid seed maturation. Horticultura Brasileira 18: 1040-1041 (in Portuguese, with abstract in English).

Nonogaki, H. 2006. Seed germination: the biochemical and molecular mechanism. Breeding Science 56: 93-105.

Pathare, P.B.; Opara, U.I.; Al-Said, E.A. 2013. Colour measurement and analysis in fresh and processed foods: a review. Food Bioprocess Technology 6: 36-60.

Sanchez, V.M.; Sundstrom, F.J.; McClure, G.N.; Lang, N.S. 1993. Fruit maturity, storage and postharvest maturation treatments affect bell pepper (Capsicum annuum L.) seed quality. Scientia Horticulturae 54: 191- 201.

Setubal, J.W.; Nascimento, W.M. 2014. Okra seed production $=$ Produção de sementes de quiabo. p. 289-315. In: Nascimento, W.M., ed. Vegetable seed production = Produção de sementes de hortaliças. Embrapa Hortaliças, Brasília, DF, Brazil (in Portuguese).

Silva, P.P.; Barros, A.C.S.A.; von Pinho, E.V.R.; Nascimento, W.M. 2015. Physiological analysis and heat-resistant protein (LEA) activity in squash hybrid seeds during development. Journal of Seed Science 37: 185-191.

Silva, V.N.; Cicero, S.M.; Bennett, M.A. 2012. Relationship between eggplant seed morphology and germination. Revista Brasileira de Sementes 34: 597-604.

TeKrony, D.M.; Egli, D.B. 1997. Accumulation of seed vigour during development and maturation. p. 369-384. In: Ellis, R.H.; Black, M.; Murdoch, A.J., eds. Proceedings of the fifth international workshop on seeds. Kluwer, Reading, UK.

Vertucci, C.W.; Farrant, J.M. 1995. Acquisition and loss of desiccation tolerance. p. 237-272. In: Kiegel, J.; Galili, G., eds. Seed development and germination. Marcel Dekker, New York, NY, USA.

Vidal, A.; Talens, P.; Prats-Montalbán, J.B.; Cubero, S.; Albert, F.; Blasco, J. 2013. In line estimation of standard colour index of citrus fruits using a computer vision system developed for a mobile platform. Food Bioprocess Technology 6: 3412-3419.

Vidigal, D.S.; Dias, D.C.F.; von Pinho, E.R.V.; Dias, L.A.S. 2009. Sweet pepper seed quality and lea-protein activity in relation to fruit maturation and post-harvest storage. Seed Science and Technology 37: 192-201.

Vidigal, D.S.; Dias, D.C.F.S.; Naveira, D.S.P.C.; Rocha, F.B.; Bhering, M.C. 2006. Physiological quality of tomato seeds in relation to fruit age and post-harvest storage. Revista Brasileira de Sementes 28: 87-93 (in Portuguese, with abstract in English).

Villiers, T.A.; Edgcumbe, D.J. 1975. On the cause of seed deterioration in dry storage. Seed Science and Technology 3: 761-764.

Wendt, L.; Gomes-Junior, F.G.; Zorato, M.F.; Moreira, G.C. 2014. Evaluation of the physiological potential of soybean seeds by image analysis. Pesquisa Agropecuária Tropical 44: 280-286 (in Portuguese, with abstract in English). 